\title{
Orchids Diversity in the Sicikeh-Cikeh Forest, North Sumatra, Indonesia
}

\author{
SRI HARTINI \\ Research Centre for Plant Conservation and Botanic Gardens (Bogor Botanic Gardens), Indonesian Institute of Sciences. Jl. Ir. H. Juanda No. 13, Bogor \\ 16122, West Java, Indonesia. Tel./fax.: +62-251-8322-187, `email: si_tini@yahoo.com \\ Manuscript received: 19 February 2019. Revision accepted: 23 March 2019.
}

\begin{abstract}
Hartini S. 2019. Orchids Diversity in the Sicikeh-Cikeh Forest, North Sumatra, Indonesia. Biodiversitas 20: $1087-1096$. Sicikeh-cikeh forest includes three forest areas, namely Adian Tinjoan Customary Forest, Adian Tinjoan Protection Forest, and Taman Wisata Alam Sicikeh-cikeh. Typical vegetation of this area is mountain forest with large diversity of plant species. Among the species, orchid is one of the potential plants found diversely in this location and has not yet been recorded. The exploration activities were conducted at Sicikeh-cikeh forest. Orchid exploration was conducted to collect living plants for ex situ conservation purpose. Orchid inventory, to record orchid diversity in this area, was based on plant collection by purposive random sampling. The results of the study recorded approximately 102 different species from 30 genera of orchids in this area. Typical epiphytic and terrestrial highland orchids were found and very common in Sumatra. Among the species found are endemic Sumatra, such as Coelogyne brachygyne, Coelogyne salmonicolor, Dendrobium kruiense, Epigeneium pulchellum, Thrixspermum gombakense, Corybas stenotribonos and Paphiopedilum tonsum. Interesting terrestrial orchids include Kuhlhasseltia javanica, Neuwiedia zollingeri var. javanica, Paphiopedilum tonsum, Phaius callosus, Corybas stenotribonos, Calanthe aurantiaca, Calanthe chrysoglossoides, and Calanthe pulchra. While interesting epiphytic orchids include Bulbophyllum absconditum, Bulbophyllum coloriferum, Coelogyne brachygyne, Epigenium pulchellum, Eria bractescens, Eria pachystachya, Pholidota gibbosa, and Thrixspermum amplexicaule.
\end{abstract}

Keywords: Diversity, North Sumatra, orchid, Sicikeh-cikeh

\section{INTRODUCTION}

Indonesia has two of the 25 centers of biodiversity in the world, namely Sundaland and Wallacea with around 35,000 species of plants or more than $10 \%$ of the world's plants. Of these, around 16,500 species are endemic plants (Myers et al. 2000). Conservation International (1998) stated that Indonesia ranks third after Brazil and Colombia in terms of diversity of plants. But, in terms of endemicity, Indonesia occupies the top position. If these two benchmarks are combined, Indonesia is in second place after Brazil. However, from this amount, only a small number $(6,000$ species) have known potential and benefits for food, clothing, shelter and industry.

This diversity of plants and their potential is threatened to diminish, even extinct, due to the high rate of deforestation in Indonesia. To prevent this, the Indonesian government issued a policy to increase plant conservation efforts ex-situ, as stated in Agenda 21. At the international level, in 2002 a Subsidiary Body on Scientific Technical and Technological Advice (SBSTTA) meeting was determined by 16 Global Strategy targets for Plant Conservation. Target 1 stipulates that in 2010 the flora of the world will be documented with a local name. Whereas in Target 8 , it is stated that $60 \%$ of rare plants must be conserved ex-situ and $10 \%$ of the conserved amount is included in recovery and restoration programs. Guerrant et al. (2004) state that based on the strategy of the Convention on Biological Diversity (CBD), ex-situ conservation is a legitimate method and an important tool for species conservation and is a valuable support for in-situ conservation efforts.

The Indonesian Botanic Garden has responsibility in implementing plant conservation and research activities in Indonesia. However, the four botanic gardens managed by the Indonesian Institute of Sciences (LIPI) have been able to conserve around $21.5 \%$ of all threatened plants in Indonesia. Therefore, since 2005, botanical gardens have been developed under the management of the provincial or district government, which are called Regional Botanical Gardens (Purnomo et al. 2015).

Sumatra is the 6th largest island in the world. It is certainly the largest island which is wholly-owned by Indonesia. Sumatra is a wonderful place for orchids. There are many reasons for this, primarily the even climate, with rainfall distributed throughout the year, particularly fitting the needs of epiphytes. There are 1118 species of orchids found growing in Sumatra; possibly there are still $10 \%$ of other orchid species that have not been identified. $24 \%$ of the total of Sumatran species can also be found in Thailand, $39 \%$ are also represented in Peninsular Malaysia, 39\% in Java and 38\% in Borneo, while $41 \%$ are endemic (Comber 2001).

Sicikeh-cikeh forest is one of the tropical rain forests in North Sumatra. Information about the diversity of orchids in this forest area is also very limited. The purpose of this study is to inventory orchid diversity in Sicikeh-cikeh forest area and also to enrich the orchid collection of Bogor and Samosir Botanic Gardens, Indonesia. 


\section{MATERIALS AND METHODS}

\section{Research sites}

The study was conducted in the Sicikeh-cikeh forest area in April 2012. The observed areas are Adian Tinjoan Customary Forest, Adian Tinjoan Protection Forest, and Taman Wisata Alam Sicikeh-cikeh, which are located at an altitude of 1,330-1,400 $\mathrm{m}$ asl. In the jungle of Taman Wisata Alam Sicikeh-cikeh, there are three lakes, namely Lake I, Lake II and Lake III. Lake I is about $1.5 \mathrm{~km}$ from the edge of the forest. While Lake II is about $700 \mathrm{~m}$ from Lake I, and Lake III is about $500 \mathrm{~m}$ from Lake II.

According to map released by BBKSDA of North Sumatra (2018), Adian Tinjoan Forest is located between Sitinjo and Parbuluan District. While Taman Wisata Alam Sicikeh-cikeh is located in Pancur Nauli Hamlet, Lae Hole Village, Parbuluan District, Dairi Regency, North Sumatra (Figure 1). This area is geographically located at $02^{\circ} 35^{\prime}$ $2^{\circ} 41^{\prime}$ North Latitude and $98^{\circ} 20^{\prime}-98^{\circ} 30^{\prime}$ East Longitude (BBKSDA Sumatera Utara 2018). Taman Wisata Alam Sicikeh-cikeh was designated as a conservation area based on the Decree of the Minister of Forestry No.78 / Kpts-II / 1989 dated 7 February 1989 with an area of 575 ha (Rais et al. 2016). Determination and Appointment of Adian Tinjoan forest area based on GB dated 9 September 1933 Number 47 part II Sub I register 67 covers 19,780 ha (BBKSDA Sumatera Utara 2018).

Part of the Sicikeh-cikeh forest adjacently located to Nauli Hamlet is a customary forest where most residents involved in agricultural practice. These activities were increasing with times and started to reach protected forests. The protected forest and Taman Wisata Alam Sicikehcikeh are separated by the Lae Pandaro river. This made forest of Taman Wisata Alam Sicikeh-cikeh to be less disturbed.

\section{Methods}

Orchid exploration activities are carried out by purposive random sampling (Partomihardjo and Rahajoe 2005). Observations, data collection, collection of orchids and documentation were carried out on species found on trips within the region. Tools and materials used in collecting plant material include plastic bags, sacks, raffia, mekolin labels, shovel/machete, field book, stationery, camera, GPS, cutting scissors, rubber bands and $\mathrm{pH}$ meter.

Epiphytic orchids are collected by removing orchids from the host tree, while, terrestrial orchids are collected by digging around the soil around orchids using a shovel/machete. Bulbs of orchid plant soil are covered with soil then wrapped in plastic. The collected Epiphytic orchids and terrestrial orchids are then put into plastic bags.

All collected orchids are labeled with data showing collection date, collector's name, collection number, species name, family name, and location. The data also shows coordinates, height of place to grow and other important morphological characters, such as plant habitus and height, leaf color, flower color, etc. from collected orchids, and they are noted in the field book. In addition, data on habitat is also recorded. This ecological data is needed for future use, also to determine its conservation strategy in the Bogor Botanic Gardens. A herbarium specimen is taken for identification purposes. References such as Comber $(1990,2001)$ and Seidenfaden and Wood (1992) were also used to support identification. The scientific names of all orchid species refer to The Plant List (2018). Some of the collections are taken and cultivated for conservation purposes in Bogor and Samosir Botanic Gardens.

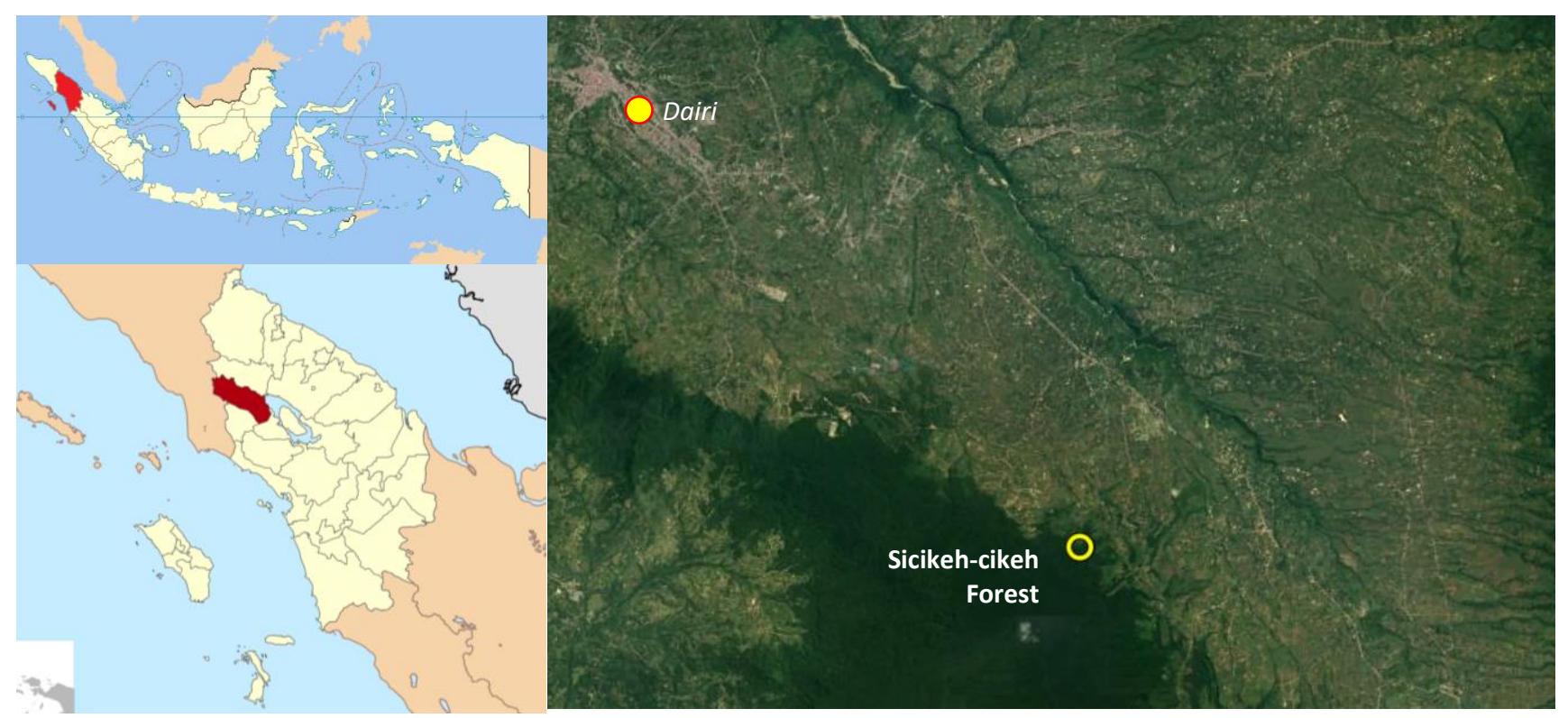

Figure 1. Map of the location of the Sicikeh-cikeh Forest, Dairi District, North Sumatra, Indonesia 


\section{RESULTS AND DISCUSSION}

Typical vegetation in Sicikeh-cikeh forest is a tropical rain forest with stratified layers of plants ranging from shrub to emergent. As with the character of rainforest, the temperature was constantly warmth, relatively humid thus supported the large diversity of plants. In addition to that, trees and open spaces often accommodate habitat for moss, cryptogam and other non vascular species. The diversity of plants obviously marked the height of the forest, namely from an altitude of $900 \mathrm{~m}$ to an altitude of $1400 \mathrm{~m}$ above sea level. At a certain height there are many incense trees (Styrax paralleloneurum), Maeang (Palaquium), Zingiberaceae (Hedychium, Zingiber, Alpinia), Araliaceae (Arthrophyllum, Brassaiopsis, Schefflera), Theaceae (Schima wallichii, Eurya nitida) and Lauraceae (Cinnamomum, Actinodaphne). Typical highland species were found with height, among others sampinur tali (Dacrydium elatum), sampinur bunga (Dacrycarpus imbricatus), Fagaceae (Lithocarpus, Quercus), Andolok species (Syzygium, Tristaniopsis whiteana), Rhododendron malayanum, $R$. sessilifolium, Nepenthes rafflesiana, $N$. reinwardtiana and many orchid species. Among the interesting groups of plants in the Sicikeh-cikeh Forest are orchids. Orchids can be found all over the forest, many of which have potential to be developed as ornamental plants (Hartini 2011).

Based on the inventory in the Sicikeh-cikeh forest, it is known that there are at least 102 species from 30 genera of orchids. The diversity of terrestrial orchids is less than that of epiphytic orchids. Research by Hutauruk (2014) on ornamental plants in the Taman Wisata Alam Sicikeh-cikeh only recorded 10 orchid species, namely Bulbophyllum binnendijkii, $B$. lobbii, $B$. tigerhianum, Coelogyne pandurata, Cymbidium lancifolium, Eria ornata, Liparis pallida, Macodes petola, Paphiopedilum tonsum, and Phaius callosus

\section{Epiphytic orchids}

The uncovered species includes the genus Adenonchos, Agrostophyllum, Appendicula, Ascidieria, Bromheadia, Bulbophyllum, Ceratostylis, Chelonistele, Coelogyne, Cymbidium, Dendrobium, Dendrochilum, Epigeneium, Eria, Flickingeria, Liparis, Oberonia, Pholidota, Podochilus, Thrixspermum, and Trichotosia. The following are interesting epiphytic orchids found in the region.

Table 1. The diversity of orchids found in the Sicikeh-cikeh forest area, North Sumatra, Indonesia




Agrostophyllum spp.

Two interesting species of Agrostophyllum were found in Sicikeh-cikeh forest, namely Agrostophyllum stipulatum subsp. bicuspidatum (J.J.Sm.) Schuit. and Agrostophyllum majus Hook.f. Both of these orchids have very different habitus. A. stipulatum subsp. bicuspidatum has a small habitus with small leaves, while A. majus is larger with flowers clustered at the end of the stem. The stems of $A$. stipulatum subsp. bicuspidatum are very close together on the short rhizome, rarely branching; the younger ones bear leaves in two rows along the whole length. Their leaves are oblong, deeply bilobed apically, about $1 \mathrm{~cm}$ long by $4 \mathrm{~mm}$ broad, sessile. While the stem of A. majus is about $2 \mathrm{~cm}$ apart on the robust rhizome, to $75 \mathrm{~cm}$ long, bearing leaves about $3.5 \mathrm{~cm}$ apart. The leaves are $10-20 \mathrm{~cm}$ long by about $1.6 \mathrm{~cm}$ broad. Both species usually grow attached to tree trunks. A. stipulatum subsp. bicuspidatum was found growing attached to a large tree in a sheltered place. A. majus is found around Lake I of Taman Wisata alam Sicikeh-cikeh, growing in a fairly open place, above litter or moss on the forest floor. A. stipulatum subsp. bicuspidatum and A. majus grow well in Sicikeh-cikeh forest. According to Comber (2001), apart from Sumatra, this species is also spread in Peninsular Malaysia, Borneo, the Solomon Islands, and Java, whereas A. bicuspidatum is widespread in Southeast Asia to the Solomon Islands (Puspitaningtyas et al. 2003).

\section{Ascidieria longifolia (Hook.f.) Seidenf.}

This species is an epiphytic orchid that grows in clumps. The stem is long, covered with leaf sheath, 10-30 cm long, supporting 2-3 leaves. The leaves are elongated, with a length of 20-24 and a width of 1-1.1 cm. Its inflorescence is a terminal, supporting many small white flowers. According to Comber (2001), this orchid is often found in moist primary or secondary forests. Generally found in the highlands at an altitude of 1000-2000 m above sea level. Its distribution area includes Thailand, Peninsular Malaysia, Sumatra, and Borneo. This orchid has collected from Mount Kerinci in West Sumatra, New Barong in Jambi, Bandar Baru and around Berastagi in North Sumatra.

\section{Bromheadia truncata Seidenf.}

This species is an epiphytic orchid that grows in small clumps, flat stems, reaching $20 \mathrm{~cm}$ long, curved, and rather stiff. The leaves are 3 on each side of the stem, curved, flat and somewhat stiff. Its inflorescence is in the terminal, short branched, appearing at the base of the uppermost leaf. The flowers are pale yellow. This orchid is found around Lake II of Taman Wisata Alam Sicikeh-cikeh, growing attached to a small tree in a fairly open place. Comber (2001) stated that apart from Sumatra, this species is spread in Thailand, Peninsular Malaysia, and Kalimantan. In Sumatra, this species is found in Jambi and North Sumatra.

\section{Bulbophyllum spp.}

About 18 species of Bulbophyllum were found in Sicikeh-cikeh forest, including B. absconditum, B. biflorum, B. coloriferum, B. coniferum, B. ecornutum, B. flavescens, $B$. odoratum, and $B$. uniflorum. Variations of each species are found in the size of the bulb, the presence or absence of bulbs, leaves, and flowers. The flowers of Bulbophyllum biflorum Teijsm. \& Binn. are arranged in one stalk in pairs. The flowers are pink with deep red dots. According to Comber (1990, 2001), this orchid usually grows in moist and wet forests, usually attached to mossy tree trunks. This orchid is spread in the Southeast Asia region. In Indonesia, it grows in Sumatra, Java and Bali.

A distinctive feature of $B$. odoratum is fragrant flowers. Inflorescence is longer than the leaves. The inflorescence of B. uniflorum arises from the rhizome, which is near the base of the pseudo tuber, with a single flower. This orchid usually grows at an altitude of 850-1,700 $\mathrm{m}$ above sea level, in a damp and wet place. The bulb of B. flavescens does not enlarge, the stalks directly attach to the rhizomes. Inflorescence arises from the growth of new shoots, as long as the leaves (Comber 1999, 2001).

\section{Ceratostylis spp.}

Two species of Ceratostylis were found in the Sicikehcikeh forest, namely Ceratostylis radiata J.J.Sm. and Ceratostylis subulata Blume. The leaves of C. radiata are larger but shorter than the leaves of $C$. subulata. Leaves of $C$. radiata are only around $10-15 \mathrm{~cm}$, with reddish-orange bulb, while $C$. subulata's leaves are as large as sticks, hard, with $20-25 \mathrm{~cm}$ long. The flowers are clustered, appearing near the tip of the leaf. According to Comber (1990, 2001), $C$. radiata is spread in Vietnam, Thailand, Peninsular Malaysia, Sumatra, Java, and Borneo. In Java, it usually grows at a trunk epiphyte in quite deep shade. The stellate flowers and the net-like old sheaths distinguish it clearly from other species. C. subulata is also spread in Peninsular Malaysia, the Philippines, Borneo, and Java. In Sumatra, this species has been found in North Sumatra (in Merek to Sidikalang) and West Sumatra (Mount Sago). Hartini et al. (2005) collected this species from the Cagar Alam Gunung Sago.

\section{Coelogyne spp.}

Three species of Coelogyne were found in Sicikehcikeh Forest, namely Coelogyne brachygyne J.J.Sm., Coelogyne pulverula Teijsm. \& Binn., Coelogyne salmonicolor Rchb.f. These three species have beautiful flowers that have the potential to be ornamental plants. The Inflorescence of $C$. brachygyne arises from the tips of young shoots. Initially, the flower stalks are upright and then bend when the weight is getting heavier. The flowers are small; the color of the flower is yellow to pale orange. Comber (2001) stated that it is endemic that can only be found in West and North Sumatra. It grows at an altitude of 1500-1850 m above sea level. Generally, it grows attached to the main stem of the tree in a rather sheltered and humid place.

Coelogyne pulverula has a slim bulb, about $12 \mathrm{~cm}$ long, rounded and grooved. The leaves are ribbon-shaped; the veins are clear, grow in groups. Besides that, the bulb is not shiny and colored. C. salmonicolor has a short rhizome, ovoid bulb and grows tightly. The inflorescence reaches 8 
$\mathrm{cm}$ long, supporting 1-4 pale orange flowers. Comber (2001) stated that this species is an endemic Sumatran orchid, which is spread along the island, starting from Lampung, Bengkulu, Jambi, West to North Sumatra. $C$. salmonicolor is suitable in a rather shady and humid place, at an altitude of 920-1300 m above sea level. C. pulverula is spread in Thailand, Peninsular Malaysia, Sumatra, Java, and Borneo.

\section{Cymbidium spp.}

Two epiphytic Cymbidium found in Sicikeh-cikeh are Cymbidium bicolor Lindl. and Cymbidium dayanum Rchb.f. Habitus of both species is similar when not flowering. The leaves of these species are in a line, hanging down, slightly weak, up to $70 \mathrm{~cm}$ long and $1-2 \mathrm{~cm}$ wide. Inflorescence of $C$. bicolor hangs down, $8-33 \mathrm{~cm}$ long and supports 5-13 fragrant flowers, maroon petal, with white or pale yellow edges, while inflorescence of C. dayanum hangs down, 20-40 cm length and supports 5-20 odorless flowers, white flowers with variations of maroon in the middle. Both orchids are widely spread. Comber (2001) informed that C. bicolor is spread in India, Sri Lanka, China, Indo-China, Sabah, Peninsula Malaysia to Sumatra, Java, Borneo and Sulawesi; while $C$. dayanum is spread in India, China, Taiwan, Japan, Thailand, Cambodia, Malaysia, Sumatra, Borneo and Sulawesi.

\section{Dendrobium spp.}

About 8 Dendrobium were found in Sicikeh-cikeh forest, including Dendrobium kruiense J.J.Sm., Dendrobium concinnum Miq., Dendrobium connatum (Blume) Lindl., and Dendrobium setifolium Ridl. D. kruiense has beautiful flowers, pink with purple tinge. This species is an endemic Sumatra orchid that was once found in North Sumatra and Bengkulu. Leaves of $D$. concinnum are arranged like braided. Inflorescence arises from its stem nodes, single flowering, with red or yellow flowers. Stems of $D$. connatum are close together, their inflorescences appear anywhere along the trunk, with a single flower. The flowers are greenish, after a few days, the flowers will turn to salmon or brownish. Whereas $D$. setifolium has a bulb that is very similar to the bulb in $D$. crumenatum, but its leaves are smaller. The flowers are white with purple lines and yellow in the center of the lips. These orchids are found on the edge of forests and open plantations, in large numbers. According to Comber (2001), D. crumenatum has only been found in the Riau Islands, but it has never been found on the main island of Sumatra.

\section{Dendrochilum spp.}

There are 7 species of Dendrochilum found in the Sicikeh-cikeh forest, one of which is Dendrochilum aurantiacum Blume. This species is an epiphytic orchid that grows sympodial and spreads. Pseudobulbs are ovalshaped, slippery, shiny, the distance between pseudo tuber is $6 \mathrm{~cm}$. The leaves are lanceolate, with short leaf stalks. Inflorescence arises from the base of the pseudo tuber, supporting 30-50 flowers. Flowers are widely open when blooming, small, red, orange or yellow. According to Comber (2001), in Sumatra, this species is not too commonly found, but has been collected from Ketambe on Mount Leuser Aceh at an altitude of 1700-2000 m above sea level. It is also found near Lake Toba at an altitude of $1525 \mathrm{~m}$ above sea level. Comber (1990) also stated that, in Java, it is found in almost all high mountain areas, generally at an altitude of $1500 \mathrm{~m}$ above sea level.

\section{Epigeneium pulchellum (Ridl.) Summerh.}

Epigeneium pulchellum (Ridl.) Summerh. has a bulb that is about $2-4 \mathrm{~cm}$ long and $1.5-2 \mathrm{~cm}$ in diameter; the leaves are oval, stiff, the edges are dull and split in two. Inflorescence appears between two leaves, more than 25 $\mathrm{cm}$ long, supporting 2-5 or more flowers which are white, yellow to dark brown. In Sicikeh-cikeh forest, this species is found around Lake I, in a very open forest floor. According to Comber (2001), this species is an orchid endemic to Sumatra. Typical specimens were collected from Mount Kerinci in West Sumatra at an altitude of 2200 $\mathrm{m}$ above sea level. It is also found on Mount Leuser in Aceh and Merek to Sidikalang in North Sumatra.

\section{Eria spp.}

There are at least 14 species of Eria found, including Eria bractescens Lindl., Eria cymbidifolia Ridl., Eria discolor Lindl., Eria hyacinthoides (Blume) Lindl., Eria iridifolia Hook.f., Eria javanica (Sw.) Blume, Eria nutans Lindl., Eria pachystachya Lindl. and Eria pilifera Ridl. These orchids have very distinctive characteristics, namely the existence of holes in the former inflorescence stems. The species that is found in almost all regions of Sicikehcikeh forest is E. iridiflora and E. cymbidifolia.

Eria cymbidifolia has 5-lines-like leaves, arranged tightly in two rows and tapered at the end. It has Axilar inflorescence, with $\pm 30 \mathrm{~cm}$ long; it is shorter than the leaves, and supports many white flowers arranged tightly. These orchids generally grow in the highlands, at 700-1950 $\mathrm{m}$ above sea level, in moist and shaded forests. Besides in Sumatra, this species is also found in Borneo. $E$. pachystachya is a clumped epiphytic orchid with slightly flattened stem that supports 5-7 leaves. The leaves are lanceolate, tip is not too sharp. Inflorescence arises from leafy stem segments, erect, shorter than the leaves, $8-15 \mathrm{~cm}$ long, supporting many small pinkish white flowers. This orchid is spread in Thailand, Peninsular Malaysia, Sumatra, and Java. E. pilifera has an erect, dangling, rather succulent stem. The leaves are thin, lanceolate, not stemmed. The inflorescence is short, only one flower, white, emerges from leafy stem segments. This species is spread in Thailand, Peninsular Malaysia, Sumatra, Java and Sulawesi.

\section{Liparis compressa (Blume) Lindl.}

Liparis compressa (Blume) Lindl. is an epiphytic creeper orchid. This orchid has a flat bulb. Inflorescence arises from the tips of old tubers, the flowers are orange, arranged in long-stemmed bunches. Comber (1990; 2001), this species is spread in Peninsular Malaysia, Sumatra, Java, Kalimantan, Sulawesi, and the Philippines. Generally, it is found in primary forests at an altitude of 700-1800 m. In Taman Wisata Alam Sicikeh-cikeh, this species was 
found near Lake II, in open place at an altitude of 1330$1360 \mathrm{~m}$ above sea level.

\section{Oberonia anceps Lindl.}

This orchid is found growing in coffee trees around the Sicikeh-cikeh forest area. This species is an epiphytic orchid that has very short stems and is covered by leaves. The leaves are thin, ribbon-shaped with pointed tip, arranged overlapping, forming like a fan. The inflorescence is terminal, about $10 \mathrm{~cm}$ long, with brownish yellow flowers. In nature, this species is spread in Cambodia, Vietnam, Burma, Peninsular Malaysia, Java, Sumatra, Borneo, Sulawesi, Maluku and the Philippines (Comber 2001).

\section{Pholidota spp.}

Seven species of Pholidota were found in the Sicikehcikeh forest, including Pholidota articulata Lindl. and Pholidota gibbosa (Blume) Lindl. ex de Vriese. The bulb on Pholidota usually supports 2 leaves. The inflorescence stalks are long, appearing between the leaves. P. gibbosa usually grows in clump with cone-shaped bulbs. Inflorescence arises from pseudo tuber, hanging down, with 20-50 cm long and fully opened flowers, light brown, rolling back away from the lips. This orchid is found around Lake II of Taman Wisata Alam Sicikeh-cikeh, growing attached to a small tree in a fairly open place. According to Comber (2001), this orchid usually grows in mountain forests at 500-1000 m above sea level, in a humid and shady place. This species spreads from Peninsula Malaysia, Sumatra, Kalimantan to Sulawesi.

Thrixspermum spp.

In Taman Wisata Alam Sicikeh-cikeh, 4 species of Thrixspermum were found, which are Thrixspermum amplexicaule (Blume) Rchb.f., Thrixspermum centipeda Lour., Thrixspermum gombakense J.J.Sm. and Thrixspermum sp. The four species have different habitus. $T$. centipeda is an epiphytic orchid, with a stem length of $10-15 \mathrm{~cm}$. The leaves are ribbon-shaped, $\pm 8 X 2 \mathrm{~cm}$, rather thick, arranged intermittently facing each other, 5-7 leaves, $1 \mathrm{~cm}$ apart. The inflorescence is long, reaching $20 \mathrm{~cm}$, supporting 2-3 pale yellow flowers, blooming together. According to Comber (2001), besides in Sumatra, this orchid is also found in India, China, Thailand, laos, Vietnam, Cambodia, Peninsular Malaysia, Borneo, Java, the Philippines and throughout Eastern Indonesia to New Guinea and N.E. Australia.

T. gombakense is an epiphytic orchid, with stiff stems, $2-5 \mathrm{~mm}$ in diameter, $3-5 \mathrm{~cm}$ between sections. The leaves are oval-shaped, blunt tip and split in two, 3-4 cm long and 1.1-1.3 cm wide. The inflorescence is short, supporting 1-2 white flowers. This species is an endemic Sumatran orchid. In Taman Wisata Alam Sicikeh-cikeh, it grows around Lake I.

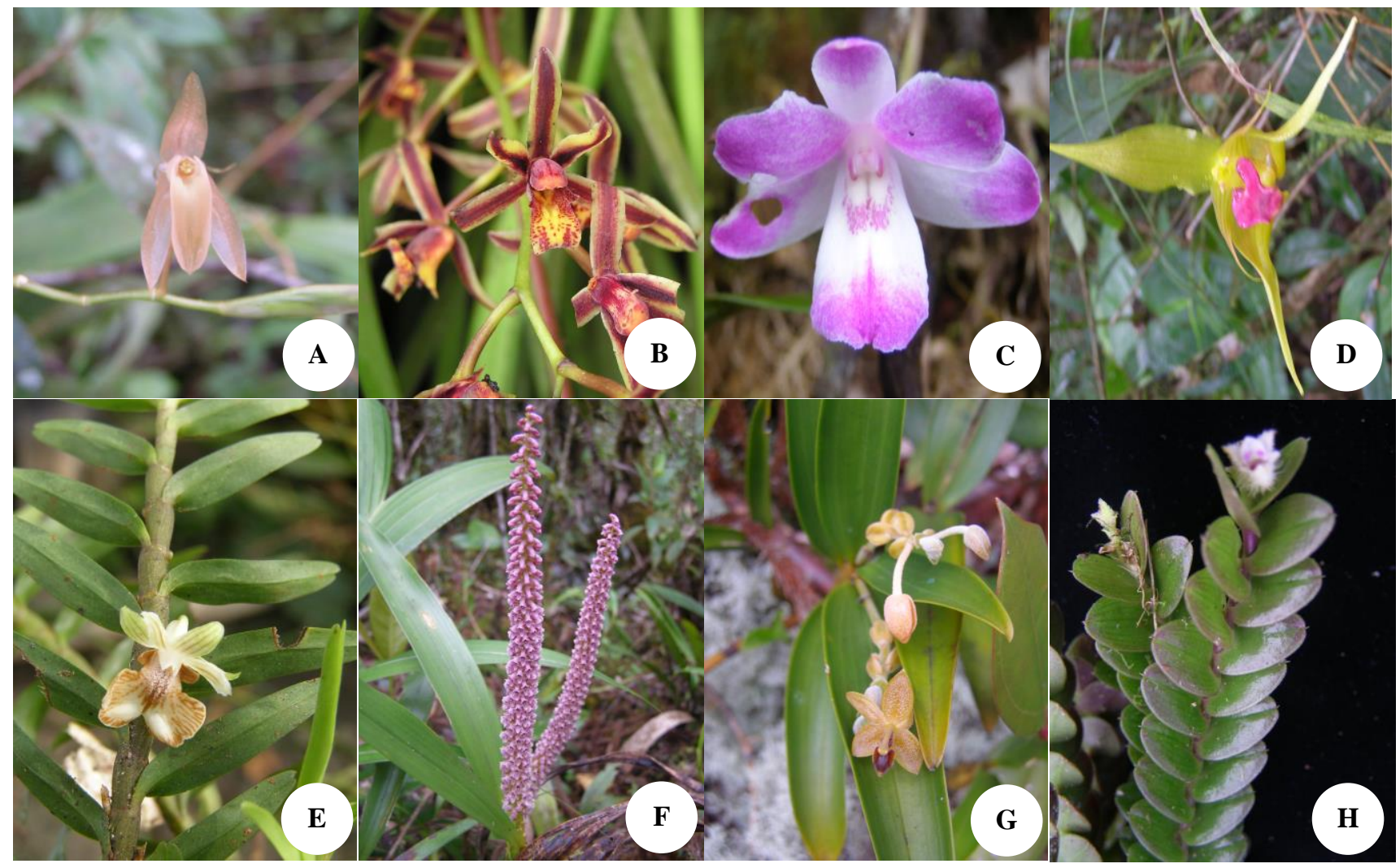

Figure 2. Epiphytic orchids of Sicikeh-cikeh Forest, North Sumatra. A. Coelogyne brachygyne, B. Cymbidium bicolor, C. Dendrobium kruiense, D. Bulbophyllum uniflorum, E. Dendrobium connatum, F. Eria pachystachya, G. Eria discolor, H. Appendicula torta 


\section{Trichotosia spp.}

There are 2 species of Trichotosia found in Sicikehcikeh forest, namely Trichotosia ferox Blume and Trichotosia velutina (Lodd. ex Lindl.) Kraenzl. Both species differ in the hairs that surround their trunks and leaves. The stem and both surfaces of $T$. ferox leaves are covered by fine reddish brown hairs. Inflorescence appears from the stem section, hanging down, $25 \mathrm{~cm}$ long, supporting 12 flowers. Flowers do not bloom simultaneously and are not fully open when flowering. Its hairy green petal is protected by hairy green leaf sheath. In Java and Sumatra, this species generally grows at an altitude of 820-1900 m above sea level, but in Sulawesi, it was once found at an altitude of $400 \mathrm{~m}$ above sea level. Comber (2001) reported that this species is widespread in Thailand, Peninsular Malaysia, Sumatra, Java, Bali, Lombok, Kalimantan, and Sulawesi. Hartini and Puspitaningtyas (2005), in North Sumatra this species is found in Taman Wisata Alam Sicikeh-cikeh, Cagar Alam Dolok Sipirok and Cagar Alam Dolok Tinggi Raja.

Trichotosia velutina has a smaller habitus than T. ferox. Fine reddish-brown hairs also cover the stem and bottom surface of the leaves, while the upper surface of the leaves is not hairy. Flowers appear on the segments of the stem opposite the leaves, arranged in groups of 2-4 flowers. The flowers are small, pale reddish yellow and the outer surface has reddish-brown hair. Comber (2001) reported that this species is widespread from Thailand, Vietnam, Burma, Peninsular Malaysia, Sumatra, Borneo, Papua New Guinea, and Solomon Islands. According to Hartini and Puspitaningtyas (2005), in North Sumatra, this species is found in Taman Wisata Alam Sicikeh-cikeh, Suaka Margasatwa Barumun, and Suaka Alam Bukit Barisan.

\section{Terrestrial orchids}

Terrestrial orchids were also found in the Sicikeh-cikeh forest, namely from the genera of Arundina, Calanthe, Corybas, Cymbidium, Liparis, Neuwiedia, Phaius, Paphiopedilum and Spathoglottis). The following are interesting terrestrial orchids found in the region.

\section{Arundina graminifolia (D.Don) Hochr.}

Arundina graminifolia (D.Don) Hochr. is a terrestrial orchid that grows clustered and is 1-2 m high. The leaves are long, linear, with a tapered tip. The terminal inflorescence clustered at the end of the stem, and only 1-2 flowers bloom at the same time. When blooming, the flower diameter is 4-9 cm, whitish pink. Lips are bright purple, wavy edges. This orchid has many flower variations in size and color. This orchid was found on the roadside to the forest area of the Taman Wisata Alam Sicikeh-cikeh, which is in a very open place. Comber (2001) stated that this orchid grows from lowland areas to highlands. It is spread in India, Sri Lanka, Nepal, South China, Taiwan and throughout the Southeast Asian region, except the Philippines.

\section{Calanthe spp.}

Some species of Calanthe grow in the Sicikeh-cikeh forest, namely Calanthe aurantiaca Ridl., Calanthe chrysoglossoides J.J.Sm., Calanthe pulchra (Blume) Lindl. and Calanthe triplicata (Willemet) Ames. C. triplicata is often called the "sleeping baby" orchid, because of the shape of his lips resemble a sleeping baby. It is a terrestrial orchid with pseudo-bulbs close together, each pseudo-bulb bearing 5-8 leaves. Leaves are lanceolate, acuminate tipped, green, $50-60 \times 10-20 \mathrm{~cm}$ on $10-20 \mathrm{~cm}$ long petioles. The inflorescence is up to $100 \mathrm{~cm}$ high, bearing dense (10-50) pure white or creamy white flowers, with short persistent green flower bracts. The flowers are pure white. In general, this orchid lives in places that lack of sunlight, litter, and moist. C.pulchra has yellow flowers with many flower arrangements and soaring above the length of the leaves. Inflorescence of $C$. aurantiaca only supports 6-10 yellow flowers. The leaves are small, ribbonshaped, pleated and clustered near the surface of the ground. This species grows on the forest floor, in colonies, between Lake I and Lake II. The leaves are almost attached to the ground sometimes overlooked as it resembles to litter. C. chrysoglossoides has a smaller number of flowers, which is around 5-7 white-pink flowers. The leaves are 1-2, lanceolate, shiny, almost no pleated.

\section{Corybas stenotribonos J.B. Comber \& J. Drans.}

This orchid was found on the forest floor of the Taman Wisata Alam Sicikeh-cikeh. The habitus is very small and blends with the forest litter, making this orchid difficult to see. The leaves are heart-shaped, hug the trunk, with pointed tip, dark green with brightly colored veins. Inflorescence is at the tip, and has single flower. According to Comber (2001), this species is endemic to Sumatra. Besides in Sicikeh-cikeh, this orchid was also found near the Merek to Sidikalang road, $1550 \mathrm{~m}$, in dense mountain forest with rather heavy shade, in leaf litter on a low ridge.

\section{Cymbidium ensifolium (L.) Sw.}

Like other Cymbidiums, this species also has linear leaves. The length of the leaves reaches $50 \mathrm{~cm}$ and the width is $1.5-2 \mathrm{~cm}$. Inflorescence arises from the tip of the stem, supporting 2-3 beautiful flowers. The flowers are yellow with brown spots. These orchids are generally found in a rather open place, both in a flat place, on a slope, or on a hill. In the Sicikeh-cikeh, this orchid is not commonly found. Comber (2001) claimed that this orchid is spread in Sri Lanka, South India, Thailand, Peninsular Malaysia, Sumatra, Java, Borneo, and New Guinea.

\section{Kuhlhasseltia javanica J.J.Sm.}

Kuhlhasseltia javanica J.J.Sm. is the only species of the Kuhlhasseltia genus found in Sumatra. It is a small terrestrial orchid which has erect stems as high as $3 \mathrm{~cm}$, support 5 leaves. The leaves are ovate, very dark red with lighter margins, $1-2.5 \mathrm{~cm}$ long by $0.8-1.5 \mathrm{~cm}$ broad. The inflorescence is comparatively long stem, the rachis is much shorter than the peduncle, with six to twelve flowers placed some distance broad. Flowers are just a little opening. This orchid was found in Taman Wisata Alam Sicikeh-cikeh, on the edge of a fairly open path, growing in groups. Comber (2001), it is also found in Java and Borneo. In Sumatra, the plant was collected by Carr from 
near Merek to Sidikalang road at about $1525 \mathrm{~m}$, and another by W.J.J.O. de Wilde from the Mount Leuser Nature Reserve, c. $15 \mathrm{~km}$ west od Kotacane at 1400-1700 m.

\section{Neuwiedia zollingeri var. javanica (J.J.Sm.) de Vogel}

This orchid is also called Neuwiedia javanica. Neuwiedia is one of the primitive orchids included in the subfamily Apostasioideae (Seidenfaden and Wood 1992; Judd et al. 1993). Apostasioideae are considered as the basic descendants in orchids based on molecular data and flower structure. Almost all subfamilies in orchids have a single stamen, but Apostasioideae orchids have 2-3 abaxial stamens. Neuwiedia has three fertile abaxial anthers, Apostasia has two fertile abaxial anthers and one sterile stamen, while the other orchids have one abaxial stamen. (Stern et al.: 1993; Pridgeon: 1999). Neuwiedia consists of 9 species which grow and are distributed in humid and protected places in Malaysia, Kalimantan, Java, the Philippines, New Guinea and the southwest Pacific. The name of this genus was given by Carl Ludwig von Blume in honor of Prince Maximilian of Wied-Neuwied. One of the species is Neuwiedia zollingeri Rchb.f. with 1 variety namely, Neuwiedia zollingeri var. javanica (J.J.Sm.) de Vogel (Dockrill 1992; Kocyan and Endress 2001; Kocyan 2004).

Neuwiedia zollingeri var. javanica usually grows in colonies and has rhizomes in the soil. Its height reaches 84 $\mathrm{cm}$, supporting 10-18 leaves. The leaves are lanceolate, with wide base and increasingly tapering towards the tip, and pleated surface. Flowers appear between the leaves at the tip of the stem, the flowering stalk is $\pm 25 \mathrm{~cm}$. Flowers are white, yellow or cream, the entire surface of the flower is covered by fine hairs. The petals are green and also covered by fine hairs. Flowers do not fully bloom and do not bloom together. The fruit is round, white and hairy. This orchid is distinguished from other varieties because of its hairs (de Vogel 1969). Comber (2001) stated that this species is spread in Sumatra, Java, and Bali. In Sumatra, this species is found on secondary forest or mixed forest floor Cagar Alam Dolok Sipirok and Suaka Margasatwa Barumun in North Sumatra (Hartini and Puspitaningtyas 2005; Hartini 2011). In Java, it is found growing at an altitude of 700-1300 m above sea level (Comber 1990).

\section{Phaius callosus (Blume) Lindl.}

Habitus of this orchid is sturdy, large, and with a height of $1 \mathrm{~m}$. The leaves are elongated, fleshy, up to $70 \mathrm{~cm}$ long. Inflorescence arises from the tip of the stem, higher than the leaves. In one inflorescence, it supports 5-12 flowers which are reddish brown in color. The lips are funnelshaped, white with purple lines on the inside. According to Comber (2001), this orchid is found especially in areas bordering protected forests, in sheltered and humid places. It is widely distributed starting from Peninsular Malaysia, Sumatra, Java, Kalimantan and Sulawesi. In Sumatra, this species was found in Taman Wisata Alam Sicikeh-cikeh and Cagar Alam Dolok Sipirok at 1000-2400 m asl (Hartini and Puspitaningtyas 2005).

\section{Paphiopedilum tonsum (Rchb.f.) Stein}

Paphiopedilum tonsum (Rchb.f.) Stein is an endemic orchid of Sumatra (Comber 2001). This orchid usually grows on the forest floor, in the shade and damp, thick hummus, at an altitude of 900-1800 m above sea level. In North Sumatra, this orchid was found in Taman Wisata Alam Sicikeh-cikeh, Taman Wisata Alam Deleng Lancuk, Cagar Alam Dolok Sipirok, Cagar Alam Dolok Sibualbuali and Suaka Margasatwa Dolok Surungan (Hartini and Puspitaningtyas 2005). In Sicikeh-cikeh, this orchid is found around Lake I and the river bank of Lae Pandaro. It supports 5-8 round-oval light green with a dark green mosaic pattern leaves. The inflorescence grows upright, reaching $30 \mathrm{~cm}$ long, supporting only one flower. The flowers are fully open with brownish yellow black spot and with a variety of stripes.

\section{Spathoglottis spp.}

Two species of Spathoglottis were found in the Sicikehcikeh forest, namely Spathoglottis aurea Lindl. and Spathoglottis plicata Blume. S. plicata is a terrestrial orchid that has an ovoid pseudobulb which is embedded underground. At the end of the pseudobulb, there will appear leaf buds with 4-7 leaves on each stem. The lanceolate leaves are elongated, the tip is tapered; the surface is rather folded. The inflorescence stalk can reach 1 $\mathrm{m}$ in length, supporting 10-30 flowers, but only 5-6 flowers that bloom simultaneously. This orchid has a variety of flower colors, ranging from bright purple, pink to white. Flowers open fully, 3.5-4 cm wide.

Spathoglottis plicata is known as Anggrek antel-antelan (Hartini and Puspitaningtyas 2005). This orchid usually grows at an altitude of $0-1600 \mathrm{~m}$ above sea level. Usually found in grasslands or on the banks of rivers, this species is widespread throughout the Southeast Asia region to New Guinea, Australia and the Pacific Islands. In the Indonesian region, it is widely spread from the tip of Sumatra to Papua (Seidenfaden and Wood 1992; Comber 2001). It was found on the roadside towards Taman Wisata Sicikeh-cikeh and also in Adian Tinjoan Customary Forest. This orchid generally grows in open places, such as grasslands and road edges, up to an altitude of $1400 \mathrm{~m}$ above sea level.

$S$. aurea is a terrestrial orchid that has an ovoid pseudobulb which supports 2-3 leaves. The lanceolate leaves are elongated, the tip is tapered; the surface is slightly folded. Inflorescence can reach $1 \mathrm{~m}$, red, supporting around 10 yellow flowers, only 1-3 flowers that bloom simultaneously. This species has a local name of Anggrek antel-antelan kuning or anggrek sendok (Hartini and Puspitaningtyas 2005). In general, this orchid grows in the highlands at $1000-1600 \mathrm{~m}$ above sea level, and is usually found in open areas or hillsides. This species is scattered in Peninsular Malaysia, Sumatra, Java and Kalimantan (Comber 1990, 2001). In Sumatra, especially in North Sumatra, it was found in Cagar Alam Dolok Sipirok, Tele-Baniara Village and Taman Wisata Alam Sicikeh-cikeh. 


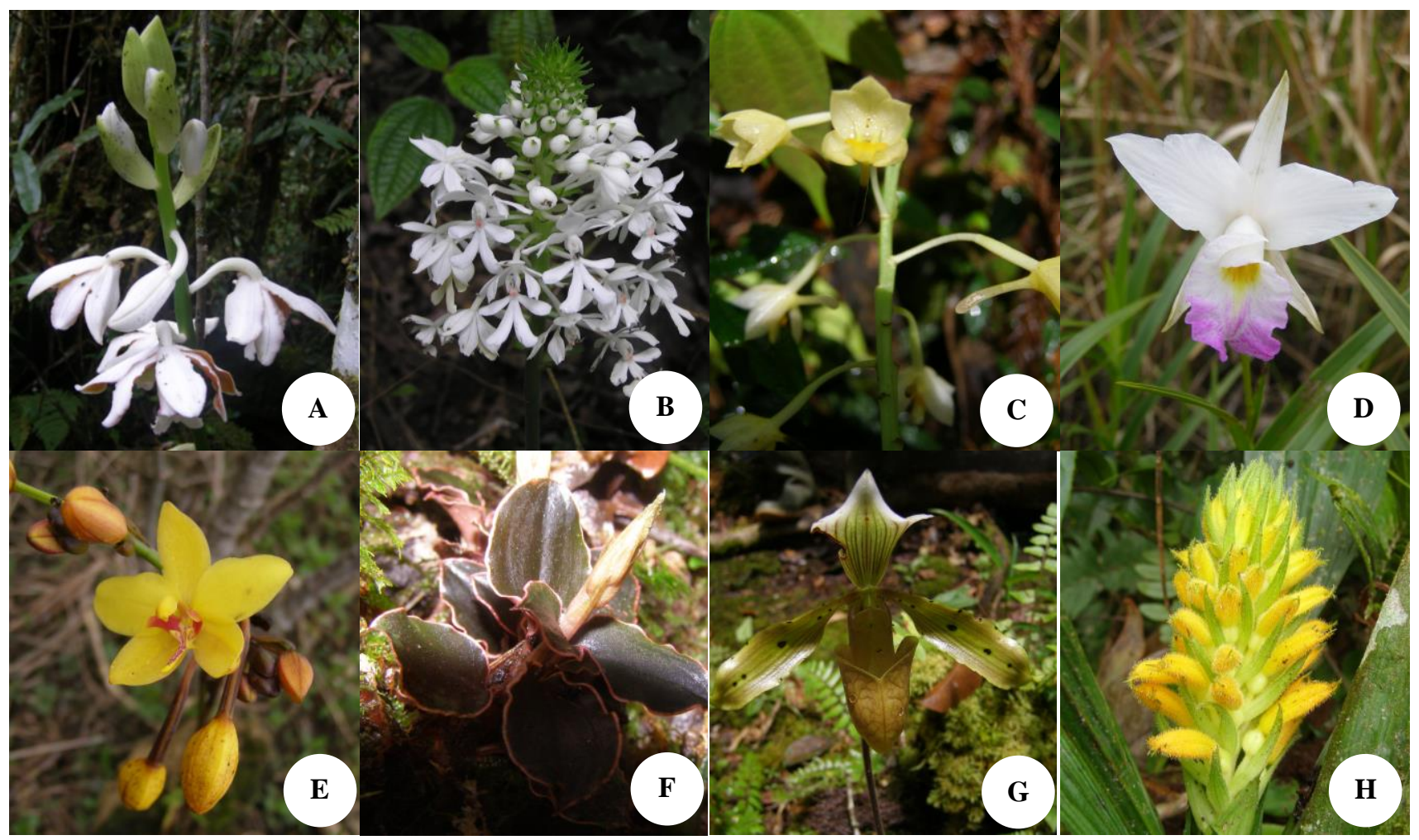

Figure 3. Terrestrial orchids of Sicikeh-cikeh forest, North Sumatra. A. Phaius callosus, B. Calanthe triplicata, C. Calanthe aurantiaca, D. Arundina graminifolia, E. Spathoglottis aurea, F. Kuhlhasseltia javanica, G. Paphiopedilum tonsum, H. Neuwiedia zollingeri var. javanica

In conclusions, the inventory of orchids in the Sicikehcikeh forest area has recorded 102 species from 30 genera including terrestrial and epiphytic orchid. Most of the orchids are typical highland species and very common in Sumatra. Among the species found are endemic Sumatra, such as Coelogyne brachygyne, Coelogyne salmonicolor, Dendrobium kruiense, Epigeneium pulchellum, Thrixspermum gombakense, Corybas stenotribonos, and Paphiopedilum tonsum. Interesting terrestrial orchids include Kuhlhasseltia javanica, Neuwiedia zollingeri var. javanica, Paphiopedilum tonsum, Phaius callosus, Corybas stenotribonos, Calanthe aurantiaca, Calanthe chrysoglossoides, and Calanthe pulchra. While interesting epiphytic orchids include Bulbophyllum absconditum, Bulbophyllum coloriferum, Coelogyne brachygyne, Epigenium pulchellum, Eria bractescens, Eria pachystachya, Pholidota gibbosa, and Thrixspermum amplexicaule. The Sicikeh-cikeh forest area is a distinctive highland tropical rainforest with high ecosystems value that supports large diversity of plant species. All orchid species depend on other plant and its living ecosystem to survive. In the era of climate change, intensive monitoring work on the diversity of this area is still urgently needed for detecting changes to this valuable forest in terms of status security and utilization of its plant diversity. Thus providing baseline information on plant and orchid diversity data is a basic step to be programmed and should be prioritized by Indonesian conservation authorities.

\section{ACKNOWLEDGEMENTS}

This study was financially supported by the Center for Plant Conservation, Botanic Gardens, LIPI, Bogor, Indonesia (DIPA 2012). The author would like to thank Sutrisno, as a Coordinator for the Program of Development of Local Botanic Gardens in Indonesia. The author offers sincere thanks to the exploration team of Sicikeh-cikeh Forest (I Wayan Mudarsa, Ngatari, Roliat Siregar, Reinheart Simarmata, Marjono Sidabutar, and Kameron Sinaga). The author is also grateful to Sofi Mursidawati who helped in writing this paper.

\section{REFERENCES}

BBKSDA Sumatera Utara. 2018. Taman Wisata Alam Sicike-cike. BKSDA Sumatera Utara, Medan. [Indonesian]

Comber JB. 1990. Orchids of Java. Bentham-Moxon Trust. The Royal Botanic Gardens, Kew, London.

Comber JB. 2001. Orchids of Sumatra. The Royal Botanic Gardens, Kew, London.

Conservation International. 1998. Megadiversity: The 17 Biodiversity Superstars. Conservation International, New York. http://www.conservation.org/documentaries/Pages/megadiversity.asp x. (September 7, 2018)

de Vogel EF. 1969. Monograph of the Tribe Apostasieae (Orchidaceae). Blumea 17 (2): 329-331.

Dockrill AW. 1992. Australian Indigenous Orchids, Volume 1 \& 2, Surrey Beatty \& Sons in association with The Society for Growing Australian Plants, Chipping Norton, NSW. 
Guerrant Jr EO, Havens K, Maunder M. 2004. Ex situ Plant Conservation: Supporting Species Survival in The Wild. Island Press, London.

Hartini S, Puspitaningtyas DM. 2005. Flora North Sumatra: exotic and potential. Center for Plant Conservation Botanic Gardens (Bogor Botanic Gardens), Indonesian Institute of Sciences, Bogor. [Indonesian]

Hartini S. 2008. Vegetation analysis report at the candidate of Samosir Botanic Garden, North Sumatra. Center for Plant Conservation Botanic Gardens (Bogor Botanic Gardens), Indonesian Institute of Sciences, Bogor. [Indonesian]

Hartini S. 2012. Exploration report: flora exploration and research in Taman Wisata Alam Sicikeh-cikeh, North Sumatra. Center for Plant Conservation Botanic Gardens (Bogor Botanic Gardens), Indonesian Institute of Sciences. Bogor. [Indonesian]

Hartini S. 2017. Terrestrial orchids in the Sicike-cike, North Sumatra Nature Parks and Conservation Efforts at the Samosir Botanical Gardens. Ecology 17 (2):-.

Hutauruk ABP. 2014. Exploration of ornamental plants in the forest area of the Taman Wisata Alam Sicike-cike in Dairi District, North Sumatra. Forestry Study Program, Faculty of Agriculture, University of North Sumatra, Medan. [Indonesian]

Judd WS, Stern WL, Cheadle VI. 1993. Phylogenetic position of Apostasia and Neuwiedia (Orchidaceae). Bot J Linn Soc 113: 87-94.

Kocyan A, Endress, PK, 2001, Floral structure and development of Apostasia and Neuwiedia (Apostasioideae) and their relationships to other Orchidaceae. Intl J Plant Sci 162: 847-867.

Kocyan A, Qiu YL, Endress PK, Conti E. 2004. A phylogenetic analysis of Apostasioideae (Orchidaceae) based on ITS, trnL-F and matK sequences. Plant Syst Evol 247: 203-213.

Myers N, Mittermeier RA, Mittermeier CG, da Fonseca GAB, Kent J. 2000. Biodiversity Hotspot for Conservation Priorities. Nature 403: 853-858.

O’Byrne P. 2001. A to Z of South East Asian Orchid Species. Orchid Society of South East Asia. Singapore.
Partomihardjo T, Rahajoe JS. 2005. The data collection of plant ecology in flora biodiversity data collection guidelines. In: Rugayah, Widjaja EA, Praptiwi (eds.). Research Center for Biology LIPI, Bogor. [Indonesian]

Pridgeon AM. 1999. Apostasioideae. In Pridgeon AM, Cribb PJ, Chase MW, Rasmussen FN [eds.]. Genera orchidacearum. Vol. 1, Oxford University Press, Oxford, UK.

Purnomo DW, Magandhi M, Kuswantoro F, Risna RA, Witono JR. 2015. Development of collections of regional botanical garden plants within the framework of Indonesian plant conservation strategies. Bot Gard Bull 18 (2): 111-124.

Puspitaningtyas DM, Mursidawati S, Sutrisno, Asikin J. 2003. Natural orchids of Java. Center for Plant Conservation Botanic Gardens (Bogor Botanic Gardens), Indonesian Institute of Sciences. Bogor. [Indonesian]

Rais S, Ruchiat Y, Hideta T, Sartono A, Rukan D, Sugandi E, Kusnadi, Sutaryono. 2007. Indonesian Conservation Area 2006. Directorate General of Forest Protection and Nature Conservation. Ministry of Forestry, Jakarta.

Sastrapradja S, Gandawidjaja D, Imelda M, Nasution RE, Roedjito W. 1979. Species of Orchids. National Biology Institute-Indonesian Institute of Sciences. Bogor. [Indonesian]

$\begin{array}{llll}\text { SBSTTA } & 12 & \text { Recommendations. }\end{array}$ http://www.cbd.int/recommendations/?rec= XII/2. (January 12, 2010)

Seidenfaden G, Wood JJ. 1992. The Orchids of Peninsular Malaysia and Singapore (A Revision of R.E. Holttum: Orchids of Malaya). Olsen \& Olsen, Fredensborg, Denmark.

Stern WL, Cheadle, V, Thorsch J. 1993. Apostasiads, systematic anatomy, and the origins of Orchidaceae'. Bot J Linn Soc 111: 411-45.

The Plant List. 2018. The Plant List, A Working List of All Plant Species Version 1.1. Published on the Internet; http://www.theplantlist.org/ (September 7, 2018). 